\title{
Detection of sugarcane yellow leaf virus (SCYLV) causing yellow leaf disease (YLD) of sugarcane using serological and molecular tools
}

\begin{abstract}
Yellow leaf disease (YLD) of sugarcane caused by Sugarcane Yellow Leaf Virus (SCYLV, a Polereovirus of the Luteoviridae family) is a serious disease affecting the crop production and productivity in India. Present study was carried out to detect the presence of ScYLV in YLD infected samples collected from the different parts of Andhra Pradesh and Telangana states from both stem sap and leaf tissue samples with both DAS-ELISA and RT-PCR tools. Some field samples showed mixed infection of both SCYLV and SCMV (Sugarcane Mosaic Virus) confirmed by electron microscopy studies. RT-PCR and ELISA assays have been standardized to detect the virus from the suspected sugarcane varieties and tissue culture derived seedlings. DAS-ELISA proved to be effective in detecting the SCYLV presence in both symptomatic and asymptomatic sugarcane plants which was further confirmed with RT-PCR.
\end{abstract}

Volume 6 Issue 2 - 2018

\author{
Suresh Madugula, Uma Devi G \\ Acharya NG ranga agricultural university, India
}

Correspondence: Suresh Madugula, Assistant Professor \& Head, Department of Plant Pathology, Agricultural College, Naira, Andhra Pradesh, 532185, India, Tel +91-9490068266, Email sureshiari@yahoo.co.in

Received: January 26, 2018 | Published: March 02, 2018

\section{Introduction}

Yellow leaf disease (YLD) is a recently identified disease of sugarcane, affecting sugarcane production significantly in all sugarcane growing areas of the world. Yellow leaf disease (YLD) of sugarcane was first reported in Hamakua (Hawaii) on variety H650782 in 1989 as yellow leaf syndrome ${ }^{1}$ and subsequently from the United States mainland ${ }^{2}$ and many other sugarcane growing countries. The disease is reported worldwide in more than 30 countries. ${ }^{3,4}$ In India, the disease is prevalent in major sugarcane growing states like Andhra Pradesh, Karnataka, Tamilnadu and Madhya Pradesh. ${ }^{5}$ Currently severe disease incidence is observed in all the sugarcane growing states in the country. The incidence of SCYLV in commercial fields can reach $100 \%$ in susceptible cultivars, and the disease can cause significant yield losses in susceptible cultivars even if infected plants do not exhibit the disease symptoms. Detection of the disease is very important as this viral disease is majorly sett borne and planting of infected sets results in severe reduction in yield as well as quality. ${ }^{6}$ Hence the present study was directed towards the detection of ScYLV using both serological and molecular tools from leaf tissue, seedlings as well as from stem sap.

\section{Experimental analysis}

\section{Collection of YLD infected plant samples}

YLD infection was observed in all the areas surveyed in Telangana and Andhra Pradesh states during 2013-14 and 2014-15 planting seasons (Table 1). Disease severity grades of 0 to 5 were recorded based on the nature of leaf symptoms, bunching of leaves in the top and overall crop growth under field conditions. ${ }^{7}$ A total of 64 infected leaf samples were collected from 7 locations in 5 different varieties of sugarcane. Irrespective of the variety grown in a particular area all the varieties showed the symptoms of YLD in varying extents. In some areas of Telangana state, both sugarcane mosaic and YLD symptoms were observed in the samples collected i.e., mixed infection (Figure 1). The mean YLD grades ranged between 0.9 (85V 36) to 4.7 (Co 95026) in different cultivars from which the samples are collected (Table 2) while the ratoon crop raised from the tissue culture plantlets of 87A 298 showed no symptoms of YLD with a mean grade of 0.0 on a scale of 0 to 5 .

\section{Electronic microscopy}

Sugarcane leaf samples with YLD symptoms and mixed infection symptoms were packed in tight containers along with dry ice and sent for Transmission Electron Microscopy (TEM) studies at Indian Agricultural Research Institute (IARI), New Delhi. The electron microscopy results also confirmed the mixed infection of the SCMV and SCYLV in some of the samples as evident from the visible symptoms observed in the field. Both the icosahedral particles of Sugarcane Yellow Leaf Virus (SCYLV) a Polero virus and flexuous filamentous rods of Sugarcane Mosaic Virus (SCMV) a Poty virus are seen in the TEM photos of partially purified leaf samples of sugarcane collected from Telangana region (Figure 2). These results confirm the incidence of both viral diseases at the same time leading to increased disease severity levels. The disease incidence levels were as high as $80 \%$ in Medak area, from where the samples having mixed infection of both YLD and Mosaic were collected. Viswanathan ${ }^{8}$ reported the increased severity of YLD under mixed infection with other diseases like sugarcane mosaic. Under field conditions also the mixed infection of these two diseases was clearly observed in varieties like 2001A 63 both at RARS farm and farmers' fields.

\section{Serological studies - DAS-ELISA}

DAS-ELISA was carried out using the kit obtained from M/s. AC Diagnostics, USA (Code-V093-K1) following the standard protocol and observations were taken visually and the colour change was observed photo metrically at $405 \mathrm{~nm}$ using thermofischer scientific 
Multi scan- X, ELISA reader and the readings were documented. Visual observations on micro titre plate as well as ELISA reader gave clear indication of the presence or absence of the SCYLV in both the varieties as well as in the tissue culture plants with respect to colour change. DAS-ELISA test results were treated as positive if the absorbance value (OD 405) is more than 0.626 i.e., more than two times the OD 405 value of negative control (OD405 $=0.313$ ), whereas as negative if absorbance value is less than that value. ${ }^{9}$

Table I Details of collection of Yellow Leaf Disease (YLD) infected sugarcane samples

\begin{tabular}{|c|c|c|c|c|}
\hline S.No & Location of the Sample & Varieties & No of Samples & $\begin{array}{l}\text { Average YLD } \\
\text { Incidence (\%) }\end{array}$ \\
\hline 1 & RARS, Anakapalle farm & Co 997, Co 6907, Co 7219 \& Co 7219 & 12 & 20 \\
\hline 2 & Chodavaram, Visakhapatnam district & $2001 \mathrm{~A} 63 \& 81 \mathrm{~V} 48$ & 8 & 15 \\
\hline 3 & Munagapaka, Visakhapatnam district & $85 \mathrm{~V} 36 \& 83 \mathrm{~A} 30$ & 15 & 20 \\
\hline 4 & Samalakot, East Godavari district & $91 \mathrm{~V} 83,2003 \mathrm{~V} 46$ & 6 & 50 \\
\hline 5 & RARS, Anakapalle farm & $\begin{array}{l}\text { Co 419, CoA } 13322 \text { and 13327, Co } \\
\text { 7706 \& 87A } 298 \text { (TCP)* }\end{array}$ & 11 & 25 \\
\hline 6 & Basantpur, Medak & Co 86032 \& Clone 22 & 5 & 65 \\
\hline 7 & Zaheerabad, Medak & CoTL579 \& 97A 401 & 7 & 80 \\
\hline
\end{tabular}

*TCP,Tissue culture plants

Table 2 Detection of ScYLV in different sugarcane genotypes based on visual grade confirmed by RT- PCR and DAS- ELISA (from both stem sap and leaf tissue samples)

\begin{tabular}{|c|c|c|c|c|c|c|c|}
\hline S. No & Genotype & & $\begin{array}{l}\text { Mean YLD } \\
\text { grade }\end{array}$ & $\begin{array}{l}\text { Visual symptom } \\
\text { expression \# }\end{array}$ & $\begin{array}{l}\text { RT- PCR } \\
\text { reaction }\end{array}$ & $\begin{array}{l}\text { DAS ELISA } \\
\text { reaction }\end{array}$ & $\begin{array}{l}\text { OD } 405 \\
\text { value @ }\end{array}$ \\
\hline I & $91 \mathrm{~V} 83$ & Bud chip raised seedling & 2.4 & + & + & + & 1.254 \\
\hline 2 & $2003 \vee 46$ & $\begin{array}{l}\text { Single node seedling - } \\
\text { stem sap }\end{array}$ & 2.9 & + & + & + & 1.248 \\
\hline 3 & $2001 \mathrm{~A} 63$ & $\begin{array}{l}\text { Single node seedling - } \\
\text { leaf tissue }\end{array}$ & 3.8 & ++ & + & + & 3.299 \\
\hline 4 & $8 I V 48$ & Ratoon - stem sap & 1.2 & + & + & + & 1.321 \\
\hline 5 & $85 \vee 36$ & Ratoon - leaf tissue & 0.9 & + & + & + & 1.097 \\
\hline 6 & Clone 22 & Ratoon - stem sap & 1.8 & + & + & + & 1.284 \\
\hline 7 & $83 \mathrm{~A} 30$ & Plant crop - stem sap & 2.6 & + & + & + & 1.294 \\
\hline 8 & CoTL 579 & Plant crop -leaf tissue & 4.4 & ++ & + & + & 2.094 \\
\hline 9 & Co 86032 & Plant crop -stem sap & 3.1 & ++ & + & + & 3.131 \\
\hline 10 & $97 A 401$ & Plant - stem sap & 4.6 & ++ & + & + & 3.128 \\
\hline II & Co 95026 & Plant -stem sap & 4.7 & ++ & + & + & 2.135 \\
\hline 12 & Co 997 & Plant - stem sap & 1.4 & + & + & + & 1.138 \\
\hline 13 & Co 6907 & Plant - stem sap & 1.3 & + & + & + & 2.189 \\
\hline
\end{tabular}


Table Continued......

\begin{tabular}{|c|c|c|c|c|c|c|c|}
\hline S. No & Genotype & & $\begin{array}{l}\text { Mean YLD } \\
\text { grade }\end{array}$ & $\begin{array}{l}\text { Visual symptom } \\
\text { expression \# }\end{array}$ & $\begin{array}{l}\mathbf{R T}-\mathbf{P C R} \\
\text { reaction }\end{array}$ & $\begin{array}{l}\text { DAS ELISA } \\
\text { reaction }\end{array}$ & $\begin{array}{l}\text { OD } 405 \\
\text { value @ }\end{array}$ \\
\hline 14 & Co 7219 & Plant - stem sap & I.I & + & + & + & 2.184 \\
\hline 15 & Co 419 & I ratoon -stem sap & I.I & + & + & + & 1.184 \\
\hline 16 & CoA 13322 & II ratoon -stem sap & 2.5 & + & + & + & 2.175 \\
\hline 17 & CoA 13327 & II ratoon - leaf tissue & 1.5 & + & + & + & 1.986 \\
\hline 18 & Co 7706 & Plant - stem sap & 2.6 & + & + & + & 2.313 \\
\hline \multirow[t]{2}{*}{19} & 87A 298 & Ratoon - leaf tissue & 0 & - & - & - & 0.075 \\
\hline & \multicolumn{7}{|c|}{$(\mathrm{TCP})$ - check } \\
\hline 20 & $\begin{array}{l}\text { Positive } \\
\text { control }\end{array}$ & AC Diagnostics, USA & NA & NA & NA & + & I.777 \\
\hline 21 & $\begin{array}{l}\text { Negative } \\
\text { control }\end{array}$ & AC Diagnostics, USA & NA & NA & NA & - & 0.313 \\
\hline
\end{tabular}

\# +, Mid rib yellowing, no stunting; ++ , Mid rib yellowing coupled with stunting and tip drying.

@ OD 405 values more than 2 times the negative control (row 2I) are considered as positive for the test (Ref:Viswanathan 2002). ScYLV- Sugarcane Yellow Leaf Virus; RT- PCR - Reverse Transcriptase Polymerase Chain Reaction; DAS- ELISA- Double Antibody Sandwich ELISA.

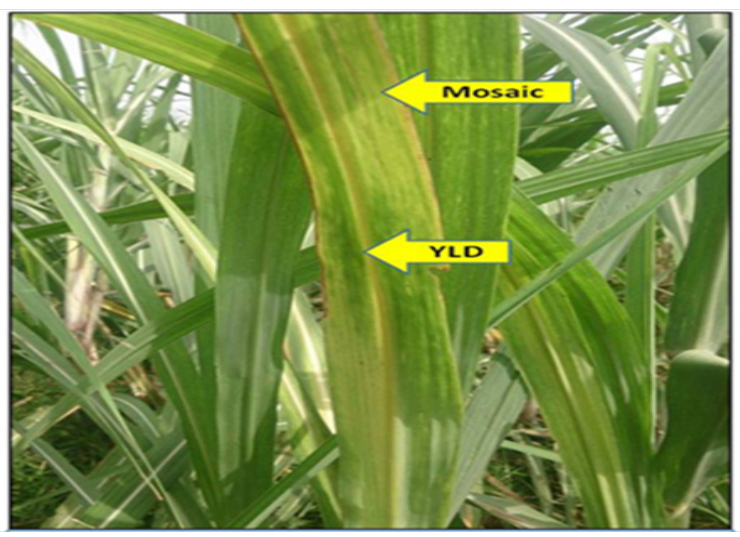

Figure I Sugarcane plants (variety 200IA 63) showing mixed infection of mosaic and YLD

All the 19 samples with typical YLD symptoms under field conditions were tested positive in DAS-ELISA, with OD 405 values $(\mathrm{nm})$ ranging between 1.097 to 3.299 (Table 2), thus confirming the effectiveness of this serological test towards detection of the virus in plant samples. Further, samples tested with stem sap and leaf tissue of the varieties expressing YLD symptoms were confirmed for the presence of the virus in DAS-ELISA. Whereas the ratoon crop raised from the tissue culture plants of 87A 298 tested negative with ELISA confirming the efficacy of tissue culture technique towards elimination of the virus. SCYLV often persists in the plants without being noticed by the growers, in fact, this non-symptomatic stage seems to be the most common epidemiological state for this viral pathogen. A screening in Hawaii revealed that all plants of susceptible

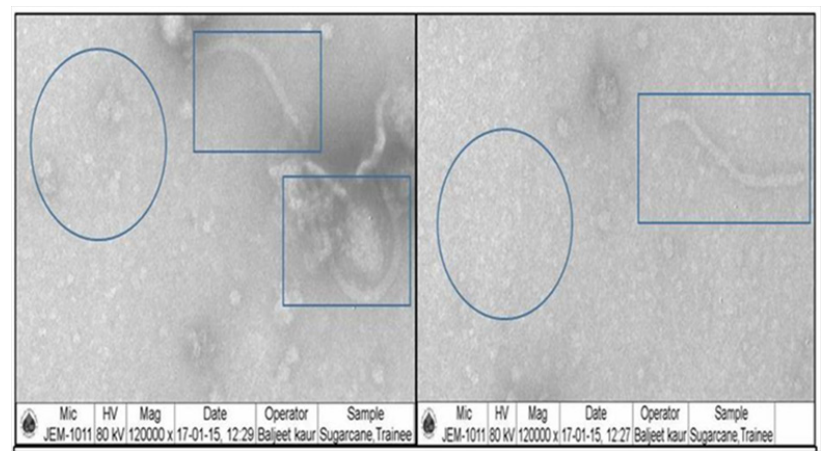

Figure 2 TEM photographs of partially purified leaf samples having mixed infection of SCMV (in rectangular boxes as flexuous rods) and SCYLV (in circle as small spherical/icosahedral particles)

TEM, Transmission Electron Microscope; SCMV, Sugarcane Mosaic Virus; ScYLV, Sugarcane Yellow Leaf Virus.

cultivar were infected with SCYLV, but disease symptoms appeared only occasionally. The severity of symptom expression varied with the seasonal variations as it was more pronounced during the cooler winter months. Symptoms also often appeared as plants aged or when they suffered from drought stress. ${ }^{10}$ Thus, this test is very useful for detecting the virus even when the plants didn't show any symptoms but still have the virus. Further, the DAS-ELISA conducted using stem sap extracted using a manual pouch piercer and the leaf samples extracted using extraction buffer didn't showed any difference in detection either with colour change or with OD 405 values (Table 2). Earlier Viswanathan \& Balamuralikrishnan ${ }^{11}$ established that DASELISA could be used to diagnose the virus infection in sugarcane using juice of sugarcane stalks. Thus, instead of extracting juice from 
stalks, a small volume of stem sap can be used for effective indexing of the virus which makes the detection quick and more economical compared to the time and cost driven leaf extraction.

\section{Molecular detection through RT-PCR}

Total plant RNA isolation was carried out following both Trizol method following the standard protocol ${ }^{12}$ with slight modification as per our lab conditions. The RNA thus obtained was utilized for further RT-PCR using Eppendorf Thermocycler. RT-PCR was standardized for the detection of SCYLV for the local lab conditions. Primers SCYLV $613 \mathrm{~F}$ and SCYLV $613 \mathrm{R}$ of coat protein region (CP) were used for the study with expected amplicon size of 613bp. All the samples were tested with RT-PCR and the samples showed positive reaction for the virus in RT-PCR test with presence of a band at around 613 base pair length confirming the presence of SCYLV in all samples (Figure 3). This confirms the earlier results ${ }^{13}$ where in the authors detected the presence of the virus through RT-PCR in almost all the 44 varieties tested in the study while only 34 entries showed the typical disease symptoms at field level. So, RT-PCR is used as a confirmatory test to determine the sensitivity of ELISA. Tissue culture plants derived ratoon crop of 87A 298 tested negative for the virus with RT-PCR affirming the DAS-ELISA reaction. Different serological techniques such as immunosorbent electron microscopy (ISEM), ELISA and immuno blot are available for the detection of the virus along with molecular tools such as RT-PCR. Production of highly specific antiserum to SCYLV, following purification of recombinant viral coat protein from E. coli, was reported to be highly specific and a reliable method for the detection of the virus in the infected host. Schenk ${ }^{14}$ developed tissue blot immunoassay (TBIA) technique using polyclonal antisera to detect SCYLV. Moutia \& Saumtally ${ }^{15}$ reported suitability of double antibody sandwich-enzyme linked immunoassay (DAS ELISA), immune specific electron microscopy (ISEM) and TBIA for the detection of the virus from the suspected sugarcane clones. They also found the presence of the virus in many of the asymptomatic plants through these techniques. Korimbocus ${ }^{16}$ expressed the virus coat protein and read through domain of SCYLV in a bacterial expression system and using the purified protein they have developed monoclonal antibodies. They have developed TBIA to detect SCYLV using the serum. TBIA has been the most widely used technique to detect the virus in different countries. ${ }^{14,17,18}$ Subsequently RT-PCR was developed to detect the virus in sugarcane.

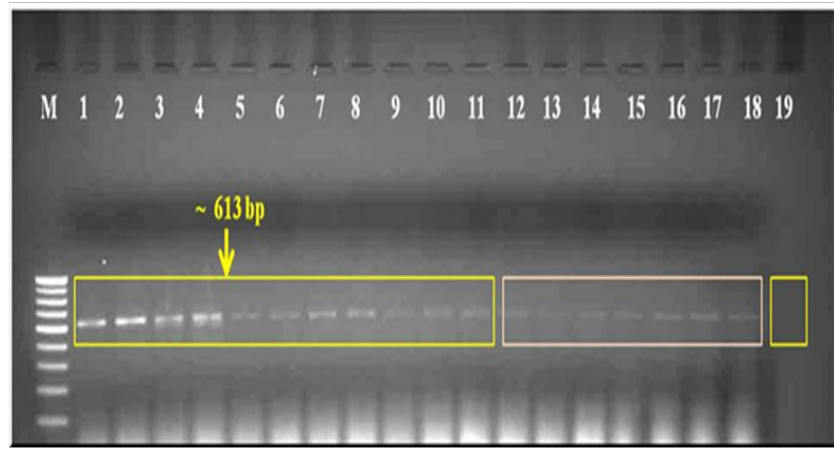

Figure 3 Agarose gel electrophoresis of RT-PCR of different sugarcane genotypes screened for YLD, Yellow Leaf Disease; AP, Andhra Pradesh (India); RARS, Regional Agricultural Research Station Anakapalle, Visakhapatnam, India; TCP,Tissue culture plants.

\section{Conclusion}

The present investigation confirmed the mixed infection of sugarcane plants with SCMV and SCYLV as a very common situation in most of the sugarcane fields. Transmission Electron Microscopy studies clearly showed the presence of both SCYLV and SCMV in samples having mixed infection. DAS-ELISA proved to be effective in detecting the SCYLV presence in both symptomatic and asymptomatic sugarcane plants which was further confirmed with RTPCR. The study found that both stem sapand leaf tissue can be used for detection of the virus for DAS-ELISA. Primers SCYLV $613 \mathrm{~F}$ and SCYLV $613 \mathrm{R}$ of coat protein region (CP) used in the present study found effective in detecting SCYLV even under mixed infection conditions.

\section{Acknowledgements}

Authors are grateful to Dr K Rajareddy, Director of Extension, ANGRAU and Dr N Venugopala Rao, PS, P\&M Cell, ANGRAU for providing necessary financial and technical support during the period of study.

\section{Conflict of interest}

Author declares there is no conflict of interest.

\section{References}

1. Schenck S. Yellow leaf syndrome - a new disease of sugarcane. Report of HSPA Experimental Station. 1990; 98p.

2. Comstock JC, Irvine JE, Miller JD. Yellow leaf syndrome appears on the United States mainland. Sugar Journal. 1994;33-35.

3. Lockhart BEL, Cronjé CPR. Yellow leaf syndrome. In: Rott P \& Bailey RA, et al, editors. A guide to sugarcane diseases. 2000; pp. 291-295.

4. Schenck S. Sugarcane yellow leaf syndrome: history and current concepts. In: Rao GP \& Ford RE, et al, editors. Sugarcane Pathology, USA: Science Publishers Inc. 2001; p. 25-35.

5. Viswanathan R, Rao GP. Disease scenario and management of major sugarcane diseases in India. Sugar Tech. 2011;13(4):336-353.

6. Suresh Madugula, Uma Devi G, Adilakshmi Devi D, et al. Impact of Set disinfection treatments on Yield and Growth parameters in Sugarcane and Management of Yellow Leaf Disease (YLD) caused by Sugarcane yellow leaf virus (SCYLV). International Journal of Bio-resources and Stress Management. 2016;7(4):862-869.

7. Viswanathan R, Chinnaraja C, parameswari B, et al. Status of yellow leaf resistance in sugarcane germplasm and parental clones at Sugarcane Breeding Institute, India. International Sugar Journal. 2016;118(1405):60 71

8. Viswanathan R. Sugarcane Breeding Institute, Coimbatore. Sugarcane Diseases and Their Management. 2012; 140p.

9. Viswanathan R. Sugarcane yellow leaf syndrome in India: Incidence and effect on yield parameters. Sugar Cane International. 2002;20(5):17-23.

10. Schenck S, Lehrer AT. Factors affecting the transmission and spread of sugarcane yellow leaf virus. Plant Disease. 2000;84:1085-1088.

11. Viswanathan R, Bala muralikrishnan M. Detection of sugarcane yellow leaf virus, the causal agent of yellow leaf syndrome in sugarcane by DASELISA. Archives of Phytopathology and Plant Protection. 2004;(37):169176.

12. Vega I, Scagliusi SM, Ulian EC. Sugarcane yellow leaf disease in Brazil: Evidence of association with a luteovirus. Plant Disease.1997;(81):21-26. 
13. Viswanathan R, Karuppaiah R, Malathi P, et al. Diagnosis of Sugarcane yellow leaf virus in asymptomatic sugarcane by RT-PCR. Sugar Tech. 2009;11(4):368-372.

14. Schenck S, Hu JS, Lockhart BEL. Use of a tissue blot immunoassay to determine the distribution of sugarcane yellow leaf virus in Hawaii. Sugar Cane. 1997;(4):5-8.

15. Moutia JFY, Saumtally S. Symptomology of yellow leaf syndrome and detection and distribution of sugarcane yellow leaf virus in Mauritius. Proceedings of International Society of Sugar Cane Technologists. 1999;(24):451-455.
16. Korimbocus J, Coates D, Barker I, et al. Improved detection of sugarcane yellow leaf virus using a real-time fluorescent (Taq Man) RT-PCR assay. Journal of Virological Methods. 2000;103(2):109-120.

17. Comstock JC, Irey MS, Lockhart BEL, et al. Incidence of yellow leaf syndrome in CP cultivars based on polymerase chain reaction and serological techniques. Sugar Cane. 1998;(4):21-24.

18. Victoria JI, Avellaneda MC, Angel JC, et al. Resistance to Sugarcane yellow leaf virus in Colombia. Proceedings of International Society of Sugar Cane Technologists. 2005;(25):664-670. 